\title{
Economic impact of tissue testing and treatments of metastatic NSCLC in the era of personalized medicine
}

\section{Donna M. Graham and Natasha B. Leighl*}

Department of Medicine, Division of Hematology and Oncology, Princess Margaret Cancer Centre, University of Toronto, Toronto, ON, Canada

\section{Edited by:}

Barbara Melosky, British Columbia

Cancer Agency, Canada

\section{Reviewed by:}

Alex Zhavoronkov, The Biogerontology

Research Foundation, UK

Meng Xu Welliver, The Ohio State

University James Cancer Center, USA

*Correspondence:

Natasha B. Leighl, Department of Medicine, Division of Hematology and Oncology, Princess Margaret Cancer Centre, University of Toronto,

610 University Avenue, Toronto,

Ontario M5G 2M9, Canada

e-mail: natasha.leighl@uhn.ca
A paradigm-shift in the management of non-small cell lung cancer (NSCLC) has resulted in many new therapies becoming available for patients with advanced disease. Stratification of treatment by histologic and molecular subtype is recommended to obtain the greatest clinical benefit for patients while minimizing adverse effects of treatment. However, these advances in diagnosis and treatment of NSCLC have come at a financial cost. This review highlights the economic impact of screening for molecular abnormalities and targeted treatment for advanced NSCLC. Major determinants of cost are drug acquisition and molecular testing. As technologies advance, molecular testing costs may reduce. However, we must collaborate with payers and manufacturers to ensure that high drug costs do not limit patient accessibility to potentially beneficial treatment.

Keywords: metastatic NSCLC, economic impact, tissue testing, personalized medicine, medical economics

\section{INTRODUCTION}

Increasing understanding of the biology of cancer has resulted in strategies to personalize therapy for patients. In advanced non-small cell lung cancer (NSCLC), these advances have led to stratification of treatment by histological and molecular subtype to obtain the greatest clinical benefit, while minimizing adverse effects of treatment (1-3). However, these innovations in diagnosis and treatment of NSCLC have come at a financial cost. Where cure is not an option, the impact of cost is a significant consideration in provision of cancer care.

\section{TREATMENT FOR NSCLC}

The SWOG 9509 (4) and ECOG 1594 (5) studies established platinum-based doublet chemotherapy as the treatment of choice in advanced NSCLC. These studies did not demonstrate benefit between treatment regimens for any subgroup analyzed. However, comparison of pemetrexed with docetaxel as second-line therapy (6), and a subsequent randomized trial comparing the combination of pemetrexed/cisplatin with gemcitabine/cisplatin as firstline treatment (7), highlighted a clinical benefit for pemetrexed in patients with non-squamous histology, giving the first suggestion that NSCLC can no longer be treated as one disease. Further attempts to improve outcomes included the addition of bevacizumab to platinum-doublet chemotherapy. This combination resulted in hemoptysis when used to treat patients with squamous cell carcinoma (8), resulting in selective treatment of patients with non-squamous histology only. A modest survival benefit of two months was seen in the bevacizumab arm with overall survival of 12.3 months compared with 10.3 months for the chemotherapy alone arm (9) and 4 months in the adenocarcinoma subgroup.

Further therapeutic options became available with the emergence of epidermal growth factor receptor (EGFR) tyrosine kinase inhibitors (TKIs). The presence of activating mutations in exons
18, 19, 20, and 21 of EGFR in NSCLC [in 15\% of adenocarcinoma (10)] predicts for improvements in progression-free survival, response, and quality of life with the use of EGFR TKIs for this subpopulation of patients compared to traditional chemotherapy (10-12). In addition, the presence of the echinoderm microtubule-associated protein-like 4 -anaplastic lymphoma kinase (EML4-ALK) fusion gene in 2-7\% of cases of NSCLC (13) is a target for therapy with crizotinib with enhanced response rates and progression-free survival when compared to second-line chemotherapy in pre-treated patients, and more recently first-line treatment (3). These targeted therapies have dramatically changed the diagnosis and treatment of NSCLC.

\section{COSTS OF LUNG CANCER MANAGEMENT}

Increasing costs of cancer management are a global issue. The estimated cost of cancer care in the United States (US) was $\$ 124.57$ billion in 2010, with a minimum estimated cost of lung cancer care being $\$ 12.12$ billion. Using the most conservative estimates, this cost was predicted to increase by $25 \%$ to $\$ 15.19$ billion by 2020 (14). However, this does not account for changes in treatment strategy and the introduction of novel agents. Canadian data have shown that the proportion of patients receiving systemic therapy has doubled from 18.1 to $37.5 \%$ from 1997 to 2007 but that the treatment costs tripled during this interval (15). Cost is of major concern to patients and payors, with medical debt being the most common cause of personal bankruptcy in the US (16). Molecularly targeted agents, while providing clinical benefit, carry a high price tag. The monthly cost of the EGFR TKI erlotinib is \$2,847CAD (Canadian dollars), and the ALK TKI crizotinib costs $\$ 10,400 \mathrm{CAD}$ for a month's supply (17). Additional expenses may also apply, including overhead costs, within certain countries.

With the expanding use of targeted therapies in this population, even greater increases in the cost of lung cancer treatment are 
anticipated. In addition, the cost of further diagnostic testing to aid treatment selection will escalate costs in the management of lung cancer. Obtaining value for money when prescribing expensive medications is critical for patients, payors, and society.

\section{DIAGNOSTIC TESTING}

As histology and molecular subtype are such critical determinants of cancer treatment, adequate tissue sampling is vital. Approximately $70 \%$ of NSCLC is diagnosed at an advanced stage, usually by small biopsy sampling rather than surgical resection. International guidelines have recommended routine immunohistochemical staining (IHC) of all NSCLC for diagnosis, histologic subtype and molecular testing for EGFR mutation, and EML4-ALK fusion for patients with advanced NSCLC (18-20). With small tissue or cytology samples, the diagnostic yield may be compromised, resulting in a requirement for re-biopsy to obtain more tissue to accurately provide a diagnosis. In the IPASS study, $44 \%$ of patients did not have available tissue for molecular testing (12), similar to $55 \%$ of patients in the BR.21 study (2). In addition, the tumor content may be insufficient for molecular testing (21). Amount of tissue required and labor intensiveness depend on the techniques employed, e.g., IHC requires less tissue and is less costly than fluorescent in situ hybridization (FISH) or sequencing, costing \$40CAD compared with \$388CAD for FISH (22). Therefore, the availability of tissue and method of testing are of clinical and economic importance.

Standardized IHC is recommended for diagnosis of NSCLC and the determination of histologic subtype. The current gold standard for $E M L 4-A L K$ testing, used in initial clinical studies as a companion diagnostic tool, is the use of a break-apart FISH assay (Vysis ALK Break Apart FISH Probe, Abbott Molecular Inc., Des Plaines, IL, USA). However, reverse-transcriptase polymerase chain reaction, IHC, chromogenic in situ hybridization (CISH), and other techniques may also be used. The most reliable of these alternative methods is IHC, due to improved sensitivity and specificity of the antibodies (23). IHC has been shown to correlate with FISH in several studies $(24,25)$, providing a far less costly and more easily accessible method for preliminary detection of EML4-ALK fusion, which may subsequently be confirmed with FISH (26). EGFR mutation testing can be performed using Sanger sequencing, and other less labor-intensive methods of EGFR mutation testing have been developed, which may have even greater sensitivity $(27,28)$. Multiplex assays and next-generation sequencing in lung cancer samples are tested for several genomic aberrations simultaneously and usually include EGFR genotyping.

Personalized therapy relies on the presence of a predefined clinical, pathological, or molecular biomarker. Biomarkers can be incorporated into drug development by different methods. Where a biomarker is integral to the drug development process, the population are screened and pre-selected for treatment on the presence of this biomarker. In order for this to be a valid strategy, robust preclinical data must strongly support this methodology. Crizotinib (an ALK, ROS-1, and MET inhibitor) is an example of a drug that was developed using an integral approach (29). An a priori hypothesis of efficacy in patients with EML4-ALK+, ROS-1+, and $M E T$ amplified tumors was used to enroll only these subpopulations to the study. This trial design led to accelerated approval for this agent, where the relatively low frequency of $E M L 4-A L K$ in the population of NSCLC may have otherwise resulted in a negative outcome. However, there is a concern that this approach may miss activity in biomarker-negative patients who may potentially benefit from an agent, if they are excluded from clinical trials. In addition, the cost of identifying the target population in this type of study is not accounted for.

Alternatively, a biomarker may be integrated into trial design, allowing both biomarker-positive and -negative patients to receive treatment, thereby enabling assessment of benefit in both groups. In this case, all patients are tested for the presence of the biomarker, and analysis of the subpopulation of interest occurs retrospectively. This was the case with the EGFR TKIs, where the biomarker of interest was initially thought to be EGFR protein expression (30) but pre-specified subgroup analysis confirmed a greater benefit for this therapy in patients with the presence of EGFR mutation in the tumor (12, 31-33).

\section{ECONOMIC ANALYSES}

Economic analyses aim to contextualize the cost of healthcare services by providing a measure of the cost and consequences for different treatments. The gold standard for oncology is the costutility analysis. Results are commonly presented as incremental cost-effectiveness ratios (ICER) and cost per quality-adjusted life year (QALY) to give a measure of the value of the intervention based on clinical benefit and costs (34). The quality of an economic assessment is often driven by the existing clinical data to support the intervention (35).

Different paths of drug development become important in economic analyses when considering the methods by which the intervention in the target population and the comparator is defined. There are different approaches to evaluate the cost of personalized medicine. It is possible to focus only on the target population and compare the intervention with other comparators in that group. However, the cost of identifying the target population through molecular testing will not be incorporated in this design, thereby potentially underestimating total cost of therapy. An alternative approach would be to compare a strategy of testing for the target biomarker in the entire population followed by treatment of the target population, with a strategy involving no biomarker testing and standard of care therapy. However, this relies on availability of an accurate assay for biomarker assessment in order to identify the true target population as a proportion of the population as a whole. An effect on small target populations may have minimal change in outcome for the population as a whole, especially if the target population is very small, e.g., $1-2 \%$. Also, improvements in technology may result in a change of testing strategy and modified costs in the future. Another approach may be to separate the test and treat component of the analysis (26).

\section{EGFR TKIs}

These agents were developed before the optimal target population was defined. Thus, early trials in lung cancer involved unselected advanced NSCLC patients.

An economic analysis of erlotinib in previously treated otherwise unselected patients with NSCLC was performed by the NCIC clinical trials group (NCIC CTG) based on data from the NCIC 
CTG BR.21 study. An ICER of \$94,638CAD per life-year gained (LYG) (95\% confidence interval of \$52,359-429,148CAD) was identified (36). Exploratory analysis identified that treating neversmokers and patients with high tumoral EGFR gene copy number were the most cost-effective strategies. Interestingly, in patients with sensitizing EGFR mutations, treatment was associated with an ICER of $\$ 138,168 \mathrm{CAD} / \mathrm{LYG}$ compared with $\$ 87,994 \mathrm{CAD} / \mathrm{LYG}$ for patients with EGFR wild-type tumors. This likely reflects the small survival benefit noted in this study for both groups and the shorter duration of therapy in patients with EGFR wild-type tumors.

Over time, we have learned that patients with EGFR-mutated advanced NSCLC derive the greatest benefit from EGFR TKI therapy, which is superior to chemotherapy in terms of response rate, quality of life, and progression-free survival, although not in overall survival due to crossover in clinical trials, with a recent exception (35). Given this clinical benefit, a number of analyses have been performed to assess cost-effectiveness in this setting (Table 1). Using platinum-doublet chemotherapy as a comparator, a CE estimate of $\mathfrak{E 5 9 , 2 1 6 - 7 0 , 3 9 0 / Q A L Y}$ was calculated for first-line gefitinib in a British study (37), but was not considered cost effective at standard willingness-to-pay thresholds. A number of studies have also investigated the cost-effectiveness of EGFR TKI treatment with EGFR mutation testing included. Based on the IPASS study (12), a Singaporean study suggested that first-line treatment of EGFR-mutated NSCLC with gefitinib was a cost-effective strategy with a CE estimate of $\$ 77,160$ Singaporean dollars/QALY (38) compared with carboplatin/paclitaxel, carboplatin/pemetrexed, or carboplatin/pemetrexed/bevacizumab. Of note, their model included second-line gefitinib for patients treated with initial chemotherapy irrespective of EGFR genotype.

The potential for insufficient diagnostic tissue available for EGFR mutation testing $(2,12)$ prompted a study in which either no lung adenocarcinoma patient samples were tested (all received first-line chemotherapy), a second testing scenario where half of the patients had sufficient tissue for EGFR testing, or a third scenario where half of the patients had repeat tumor biopsy for EGFR testing (although 15\% still had insufficient tissue after re-biopsy). First-line erlotinib therapy resulted in an ICER of \$110,658/QALY gain compared with carboplatin/paclitaxel with the testing strategy and \$122,234/QALY using the re-biopsy strategy. With carboplatin/pemetrexed as a comparator, the ICER for the repeat biopsy strategy was \$180,665/QALY; adding bevacizumab increased the ICER significantly to $\$ 359,619 /$ QALY, in excess of commonly accepted thresholds for cost-effectiveness (39). A recent study from the perspective of the Chinese healthcare system investigated the cost-effectiveness of first-line erlotinib compared with platinum-doublet chemotherapy in advanced EGFR mutation positive lung cancer patients based on outcomes from the OPTIMAL trial (42). Treatment with upfront erlotinib was deemed cost effective with an ICER of $\$ 85,927.41$ USD/QALY gained. Of note, this analysis assumed that after the first 5 months (seven cycles) of therapy, subsequent erlotinib would be donated by Roche China.

A U.S. study demonstrated a modest budget impact of EGFR mutation testing and erlotinib as first-line therapy for patients with EGFR mutation positive advanced disease compared with platinum-doublet based chemotherapy regimens, from a U.S. health plan perspective (43). Increasing EGFR testing rates from 50 to $100 \%$ increased overall health plan expenditures by $\$ 0.013$ per member per month (PMPM). Treatment costs contributed $\$ 0.012$ PMPM with extended duration of treatment giving the greatest contribution. The cost of EGFR mutation testing was estimated at $\$ 0.002$ PMPM, but was offset by the cost-savings associated with treatment of chemotherapy-related adverse events $(-\$ 0.002$ PMPM).

Recent clinical data suggest an improvement in progressionfree and overall survival for patients with EGFR-mutant NSCLC when treated with afatinib compared with platinum-based chemotherapy $(44,45)$. Although unable to estimate a plausible ICER based on the manufacturer's submission, afatinib was considered to be a reasonable option for first or secondline treatment for patients with EGFR-mutant NSCLC, with exploratory estimates from the Evidence Review Committee of an ICER of $\mathfrak{E} 39,300 / \mathrm{QALY}$ gained with afatinib compared to pemetrexed/cisplatin in the overall population, and an ICER of $\mathfrak{E} 23,700$ /QALY gained in the non-Asian population based on trial data provided (46).

\section{ALK INHIBITORS}

The cost-effectiveness of testing methodology for EML4-ALK fusion-positive tumors has been assessed using differing techniques, from a societal perspective using the US healthcare system (26). By varying $A L K$ testing methods and population tested, the CE of FISH testing for all patients was estimated at \$106,707USD/QALY, compared with $\$ 57,165 \mathrm{USD} / \mathrm{QALY}$ for IHC. In a clinically selected population of non-smokers with EGFR - and KRAS-wild type adenocarcinoma, the CE estimates were \$4,756USD/QALY and \$2,548USD/QALY for FISH and IHC, respectively. One cost-effectiveness analysis has explored the use of crizotinib for the first-line treatment of patients with EML4$A L K$ fusion-positive tumors from the Canadian public healthcare perspective (22). The comparator was a platinum-doublet chemotherapy regimen in patients with non-squamous NSCLC, and the model incorporated subsequent treatment with pemetrexed and erlotinib. A re-biopsy strategy was employed in case of inadequate tissue. The method of assessment for EML4-ALK positive tumor was by initial IHC and, if positive, confirmatory testing with FISH. The incremental cost of crizotinib therapy for a gain of 0.11 QALYs was $\$ 2,725 \mathrm{CAD} /$ patient, with an ICER of $\$ 255,970 /$ QALY gained. For patients with confirmed EML4-ALK positive tumors, first-line therapy with crizotinib produced an ICER of \$250,632CAD/QALY, in excess of commonly accepted cost-effectiveness thresholds. Sensitivity analysis highlighted the major driver of cost as the price of crizotinib therapy. Despite FISH testing costs exceeding those of IHC, the relative cost of crizotinib was so great that use of the cost of initial FISH testing instead of IHC had minimal impact on the overall ICER.

\section{HISTOPATHOLOGY}

Patients with non-squamous NSCLC derive benefit from pemetrexed-based chemotherapy and from the addition of bevacizumab to a platinum-doublet. Although histologic subtype is not a recognized biomarker, these data have led to treatment selection 
Table 1 | Cost-effectiveness studies of first-line EGFR TKI therapy.

\begin{tabular}{|c|c|c|c|c|c|c|c|c|}
\hline Author & Type of study & $\begin{array}{l}\text { EGFR TKI and } \\
\text { comparator }\end{array}$ & Model & $\begin{array}{l}\text { Cost of } \\
\text { testing }\end{array}$ & Perspective & ICER per QALY & $\begin{array}{l}\text { Cost- } \\
\text { effective? }\end{array}$ & Remarks \\
\hline $\begin{array}{l}\text { Brown et al. } \\
\text { (37) }\end{array}$ & $\begin{array}{l}\text { Cost- } \\
\text { effectiveness } \\
\text { analysis }\end{array}$ & $\begin{array}{l}\text { Gefitinib compared with } \\
\text { platinum-doublet } \\
\text { chemotherapy }\end{array}$ & $\begin{array}{l}\text { Decision model comparing } \\
\text { gefitinib with carbo/tax in } \\
\text { patients with EGFR mutation } \\
\text { positive disease }\end{array}$ & No & $\begin{array}{l}\text { National Health } \\
\text { Service }\end{array}$ & $£ 59,216-70,390$ & No & Clinical data from IPASS: (12) \\
\hline $\begin{array}{l}\text { de Lima } \\
\text { Lopes et al. } \\
\text { (38) }\end{array}$ & $\begin{array}{l}\text { Cost-utility } \\
\text { analysis }\end{array}$ & $\begin{array}{l}\text { Gefitinib compared with } \\
\text { carbo/gem } \\
\text { Subset analysis of } \\
\text { gefitinib as second-line } \\
\text { Assumed } 60 \% \text { with } \\
\text { EGFR mutation }\end{array}$ & $\begin{array}{l}\text { Decision tree with testing } \\
\text { versus no testing and multiple } \\
\text { lines of treatment. } \\
\text { Test positive: gefitinib, } \\
\text { carbo/gem, BSC } \\
\text { Test negative: Carbo/gem, } \\
\text { BSC } \\
\text { No testing: Carbo/gem, } \\
\text { gefitinib, BSC }\end{array}$ & $\begin{array}{l}\text { Included } \\
\$ 380\end{array}$ & $\begin{array}{l}\text { Singaporean } \\
\text { health care } \\
\text { system, } 2010 \\
\text { Singapore dollars }\end{array}$ & $\$ 77,160$ & Yes & $\begin{array}{l}\text { Clinical data from } 3 \text { trials: IPASS: } \\
\text { (12);WJTOG 345: (32); } \\
\text { C000000376: (33) }\end{array}$ \\
\hline $\begin{array}{l}\text { Handorf et al. } \\
\text { (39) }\end{array}$ & $\begin{array}{l}\text { Cost- } \\
\text { effectiveness } \\
\text { analysis }\end{array}$ & $\begin{array}{l}\text { Erlotinib compared with } \\
\text { carbo/tax, carbo/pem, } \\
\text { and carbo/pem/bev }\end{array}$ & $\begin{array}{l}\text { Decision analytic model with } \\
\text { testing versus no testing and } \\
\text { re-biopsy included } \\
\text { Test positive: erlotinib } \\
\text { Test negative: platinum-based } \\
\text { chemotherapy } \\
\text { No testing or insufficient } \\
\text { tissue on repeat biopsy: } \\
\text { platinum-based } \\
\text { chemotherapy }\end{array}$ & Yes & $\begin{array}{l}\text { Payer's } \\
\text { perspective }\end{array}$ & $\begin{array}{l}\$ 110,658 \text { for } \\
\text { carbo/tax test and } \\
\text { treat } \\
\$ 122,234 \text { for } \\
\text { carbo/tax re-biopsy } \\
\$ 180,665 \text { for } \\
\text { carbo/pem } \\
\$ 359,619 \text { for } \\
\text { carbo/pem/bev }\end{array}$ & Yes & $\begin{array}{l}\text { Re-biopsy strategy included: } \\
\text { assumed 15\% yielded insufficient } \\
\text { tissue }\end{array}$ \\
\hline $\begin{array}{l}\text { Brown et al. } \\
(40)\end{array}$ & $\begin{array}{l}\text { Cost- } \\
\text { effectiveness } \\
\text { analysis }\end{array}$ & $\begin{array}{l}\text { Gefitinib compared with } \\
\text { platinum-doublet } \\
\text { chemotherapy }\end{array}$ & $\begin{array}{l}\text { Decision model comparing } \\
\text { gefitinib with cis/tax, } \\
\text { carbo/tax or cis/doc }\end{array}$ & No & $\begin{array}{l}\text { UK National } \\
\text { Health Service } \\
\text { and Personal } \\
\text { Social Services }\end{array}$ & $\begin{array}{l}\text { Mean } £ 35,700 \\
\text { (range } £ 59,216- \\
70,390)\end{array}$ & No & $\begin{array}{l}\text { Clinical data from IPASS: }(12,31) \text {; } \\
\text { WJTOG 345: (32); C000000376: } \\
\text { (33); Mean negotiated NHS costs } \\
\text { included }\end{array}$ \\
\hline $\begin{array}{l}\text { Wang et al. } \\
\text { (41) }\end{array}$ & $\begin{array}{l}\text { Cost- } \\
\text { effectiveness } \\
\text { analysis }\end{array}$ & $\begin{array}{l}\text { Erlotinib compared with } \\
\text { carbo/gem }\end{array}$ & $\begin{array}{l}\text { Markov model comparing } \\
\text { carbo/gem for } 4 \text { cycles with } \\
\text { erlotinib until progression }\end{array}$ & No & $\begin{array}{l}\text { Chinese health } \\
\text { care system, } \\
2010 \text { US dollars }\end{array}$ & $\begin{array}{l}\$ 85927.41 \text { (range } \\
\$ 58,584.57- \\
336,404.20 \text { ) }\end{array}$ & Yes & $\begin{array}{l}\text { Clinical data from OPTIMAL trial: } \\
\text { (42) } \\
\text { Cost of erlotinib included only for } \\
\text { first } 7 \text { cycles (from cycle } 8 \text { or } \\
\text { month } 5 \text { onward cost is zero due } \\
\text { to donations from Roche China) }\end{array}$ \\
\hline
\end{tabular}

EGFR TKI, epidermal growth factor tyrosine kinase inhibitor; ICER, incremental cost-effectiveness ratio; LY, life years; QALY, quality of life year; carbo/gem, carboplatin and gemcitabine chemotherapy; BSC, best supportive care; carbo/tax, carboplatin and paclitaxel; carbo/pem, carboplatin and pemetrexed; carbo/pem/bev, carboplatin, pemetrexed and bevacizumab; cis/tax, cisplatin and paclitaxel; cis/doc, cisplatin and docetaxel. 
for patients based on histologic subtype. Given the significant cost of these agents when compared with other standard chemotherapy regimens, several economic assessments have been performed. A cost-utility analysis of the addition of bevacizumab to platinumbased chemotherapy compared with chemotherapy alone (9) in patients with non-squamous NSCLC estimated an increase of 0.13 QALYs with the addition of bevacizumab, at a cost of \$72,000USD per patient. The incremental cost-utility ratio for the addition of bevacizumab was \$560,000USD/QALY (47), exceeding accepted thresholds for cost-effectiveness.

In the first-line setting, pemetrexed/cisplatin improved median overall survival by 1 month in advanced non-squamous lung carcinoma patients, when compared with gemcitabine/cisplatin, and an ICER estimated at $\mathfrak{E} 17,000-25,000 /$ QALY (48). When pemetrexed is used as maintenance, the median survival gain compared to observation is 5 months, with an ICER of $\$ 122$, 371USD/LYG.

\section{CONCLUSION}

The management of lung cancer has transformed in recent years, due to increasing stratification of treatment based on pathologic and molecular characteristics. Optimizing treatment by using personalized therapy has resulted in improved treatment responses, quality of life, and progression-free survival of patients with NSCLC, with some evidence of survival benefit. However, this comes at a price, and, acknowledging that these actionable mutations are present only in a small subset of NSCLC tumors, we must act in the best interests of all our patients to ensure that this is affordable for the benefit gained.

In order to focus on the relevant population for a molecularly targeted therapy, tissue must be available and the testing method must be accurate. However, as in the case of EML4-ALK, there may be methods to select the target population with lower cost, and these technologies will continue to evolve. Further evolution of next-generation sequencing and multiplex platforms may also improve the cost-effectiveness of testing, where multiple abnormalities can be evaluated with a single test. While molecular testing beyond $E G F R$ and $A L K$ is not currently recommended as standard of care in NSCLC (18), more comprehensive genomic testing will likely become cheaper and more accessible in the future, minimizing time and tissue requirements in efforts to better personalize therapy $(49,50)$.

Cost-effective, -accurate, and -efficient methods of diagnosis must be employed, which allow equal accessibility to therapy for all patients. However, the major cost determinant in most economic evaluations of targeted treatment in NSCLC is drug price. Economic evaluations are integral to assessment of value for a given therapy as these may be used to enable funding decisions by policy-makers, and to negotiate pricing strategies with manufacturers where possible. There has been a paradigm-shift in the treatment of NSCLC with exciting new therapies revolutionizing treatment for patients with a previously dismal prognosis. As clinicians, we must ensure that as many patients as possible derive benefit from a personalized approach. Collaboration with payers and manufacturers is a key to ensure that cost of treatment is not prohibitive for patients and permitting further advances in lung cancer therapy.

\section{REFERENCES}

1. Mantripragada K, Khurshid H. Targeting genomic alterations in squamous cell lung cancer. Front Oncol (2013) 3:195. doi:10.3389/fonc.2013.00195

2. Shepherd FA, Rodrigues Pereira J, Ciuleanu T, Tan EH, Hirsh V, Thongprasert $\mathrm{S}$, et al. Erlotinib in previously treated non-small-cell lung cancer. $N$ Engl J Med (2005) 353(2):123-32. doi:10.1056/NEJMoa050753

3. Camidge DR, Bang YJ, Kwak EL, Iafrate AJ, Varella-Garcia M, Fox SB, et al. Activity and safety of crizotinib in patients with ALK-positive non-small-cell lung cancer: updated results from a phase 1 study. Lancet Oncol (2012) 13(10):1011-9. doi:10.1016/S1470-2045(12)70344-3

4. Kelly K, Crowley J, Bunn PA Jr, Presant CA, Grevstad PK, Moinpour CM, et al. Randomized phase III trial of paclitaxel plus carboplatin versus vinorelbine plus cisplatin in the treatment of patients with advanced non - small-cell lung cancer: a southwest oncology group trial. J Clin Oncol (2001) 19(13):3210-8.

5. Schiller JH, Harrington D, Belani CP, Langer C, Sandler A, Krook J, et al. Comparison of four chemotherapy regimens for advanced non-small-cell lung cancer. N Engl J Med (2002) 346(2):92-8. doi:10.1056/NEJMoa011954

6. Hanna N, Shepherd FA, Fossella FV, Pereira JR, De Marinis F, von Pawel J, et al. Randomized phase III trial of pemetrexed versus docetaxel in patients with nonsmall-cell lung cancer previously treated with chemotherapy. J Clin Oncol (2004) 22(9):1589-97. doi:10.1200/JCO.2004.08.163

7. Scagliotti GV, Parikh P, von Pawel J, Biesma B, Vansteenkiste J, Manegold C, et al. Phase III study comparing cisplatin plus gemcitabine with cisplatin plus pemetrexed in chemotherapy-naive patients with advanced-stage non-small-cell lung cancer. J Clin Oncol (2008) 26(21):3543-51. doi:10.1200/JCO.2007.15.0375

8. Johnson DH, Fehrenbacher L, Novotny WF, Herbst RS, Nemunaitis JJ, Jablons DM, et al. Randomized phase II trial comparing bevacizumab plus carboplatin and paclitaxel with carboplatin and paclitaxel alone in previously untreated locally advanced or metastatic non-small-cell lung cancer. J Clin Oncol (2004) 22(11):2184-91. doi:10.1200/JCO.2004.11.022

9. Sandler A, Gray R, Perry MC, Brahmer J, Schiller JH, Dowlati A, et al. Paclitaxelcarboplatin alone or with bevacizumab for non-small-cell lung cancer. $N$ Engl J Med (2006) 355(24):2542-50. doi:10.1056/NEJMoa061884

10. Rosell R, Moran T, Queralt C, Porta R, Cardenal F, Camps C, et al. Screening for epidermal growth factor receptor mutations in lung cancer. N Engl J Med (2009) 361(10):958-67. doi:10.1056/NEJMoa0904554

11. Douillard JY, Shepherd FA, Hirsh V, Mok T, Socinski MA, Gervais R, et al. Molecular predictors of outcome with gefitinib and docetaxel in previously treated non-small-cell lung cancer: data from the randomized phase III interest trial. $J$ Clin Oncol (2010) 28(5):744-52. doi:10.1200/JCO.2009.24.3030

12. Mok TS, Wu YL, Thongprasert S, Yang CH, Chu DT, Saijo N, et al. Gefitinib or carboplatin-paclitaxel in pulmonary adenocarcinoma. N Engl J Med (2009) 361(10):947-57. doi:10.1056/NEJMoa0810699

13. Crystal AS, Shaw AT. New targets in advanced NSCLC: EML4-ALK. Clin Adv Hematol Oncol (2011) 9(3):207-14.

14. Mariotto AB, Yabroff KR, Shao Y, Feuer EJ, Brown ML. Projections of the cost of cancer care in the United States: 2010-2020. J Natl Cancer Inst (2011) 103(2):117-28. doi:10.1093/jnci/djq495

15. de Oliveira C, Bremner KE, Pataky R, Gunraj N, Haq M, Chan K, et al. Trends in use and cost of initial cancer treatment in Ontario: a population-based descriptive study. CMAJ Open. (2013) 1(4):E151-8. doi:10.9778/cmajo.20130041

16. Himmelstein DU, Thorne D, Warren E, Woolhandler S. Medical bankruptcy in the United States, 2007: results of a national study. Am J Med (2009) 122(8):741-6. doi:10.1016/j.amjmed.2009.04.012

17. Truven Health Analytics. Red Book online. (2014). Available from: http://www. redbook.com/redbook/index.html

18. Lindeman NI, Cagle PT, Beasley MB, Chitale DA, Dacic S, Giaccone G, et al. Molecular testing guideline for selection of lung cancer patients for EGFR and ALK tyrosine kinase inhibitors: guideline from the college of American pathologists, international association for the study of lung cancer, and association for molecular pathology. J Mol Diagn: JMD. (2013) 15(4):415-53.

19. Ellis PM, Blais N, Soulieres D, Ionescu DN, Kashyap M, Liu G, et al. A systematic review and Canadian consensus recommendations on the use of biomarkers in the treatment of non-small cell lung cancer. J Thorac Oncol (2011) 6(8):1379-91. doi:10.1097/JTO.0b013e318220cb8e

20. Kerr KM, Bubendorf L, Edelman MJ, Marchetti A, Mok T, Novello S, et al. 2nd ESMO consensus conference on lung cancer: pathology and molecular biomarkers for non-small-cell lung cancer. Ann oncol (2014;) 25(9):1681-90. doi:10.1093/annonc/mdu145 
21. Thunnissen E, Kerr KM, Herth FJ, Lantuejoul S, Papotti M, Rintoul RC, et al. The challenge of NSCLC diagnosis and predictive analysis on small samples. Practical approach of a working group. Lung Cancer (2012) 76(1):1-18. doi:10.1016/j.lungcan.2011.10.017

22. Djalalov S, Beca J, Hoch JS, Krahn M, Tsao MS, Cutz JC, et al. Cost effectiveness of EML4-ALK fusion testing and first-line crizotinib treatment for patients with advanced ALK-positive non-small-cell lung cancer. J Clin Oncol (2014) 32(10):1012-9. doi:10.1200/JCO.2013.53.1186

23. Mino-Kenudson M, Chirieac LR, Law K, Hornick JL, Lindeman N, Mark EJ, et al. A novel, highly sensitive antibody allows for the routine detection of ALKrearranged lung adenocarcinomas by standard immunohistochemistry. Clin Cancer Res (2010) 16(5):1561-71. doi:10.1158/1078-0432.CCR-09-2845

24. Paik JH, Choe G, Kim H, Choe JY, Lee HJ, Lee CT, et al. Screening of anaplastic lymphoma kinase rearrangement by immunohistochemistry in non-small cell lung cancer: correlation with fluorescence in situ hybridization. J Thorac Oncol (2011) 6(3):466-72. doi:10.1097/JTO.0b013e31820b82e8

25. Yi ES, Boland JM, Maleszewski JJ, Roden AC, Oliveira AM, Aubry MC, et al. Correlation of IHC and FISH for ALK gene rearrangement in non-small cell lung carcinoma: IHC score algorithm for FISH. J Thorac Oncol (2011) 6(3):459-65. doi:10.1097/JTO.0b013e318209edb9

26. Atherly AJ, Camidge DR. The cost-effectiveness of screening lung cancer patients for targeted drug sensitivity markers. Br J Cancer (2012) 106(6):1100-6. doi:10.1038/bjc. 2012.60

27. Kamel-Reid S, Chong G, Ionescu DN, Magliocco AM, Spatz A, Tsao M, et al. EGFR tyrosine kinase mutation testing in the treatment of non-small-cell lung cancer. Curr Oncol (2012) 19(2):e67-74. doi:10.3747/co.19.862

28. Beasley MB, Milton DT. ASCO provisional clinical opinion: epidermal growth factor receptor mutation testing in practice. J Oncol Pract (2011) 7(3):202-4. doi:10.1200/JOP.2010.000166

29. Kwak EL, Bang YJ, Camidge DR, Shaw AT, Solomon B, Maki RG, et al. Anaplastic lymphoma kinase inhibition in non-small-cell lung cancer. N Engl J Med (2010) 363(18):1693-703. doi:10.1056/NEJMoa1006448

30. Ciardiello F, Tortora G. A novel approach in the treatment of cancer: targeting the epidermal growth factor receptor. Clin Cancer Res (2001) 7(10): 2958-70.

31. Fukuoka M, Wu YL, Thongprasert S, Sunpaweravong P, Leong SS, Sriuranpong $\mathrm{V}$, et al. Biomarker analyses and final overall survival results from a phase III, randomized, open-label, first-line study of gefitinib versus carboplatin/paclitaxel in clinically selected patients with advanced non-small-cell lung cancer in Asia (IPASS). J Clin Oncol (2011) 29(21):2866-74. doi:10.1200/JCO.2010.33.4235

32. Mitsudomi T, Morita S, Yatabe Y, Negoro S, Okamoto I, Tsurutani J, et al. Gefitinib versus cisplatin plus docetaxel in patients with non-small-cell lung cancer harbouring mutations of the epidermal growth factor receptor (WJTOG3405): an open label, randomised phase 3 trial. Lancet Oncol (2010) 11(2):121-8. doi:10.1016/S1470-2045(09)70364-X

33. Maemondo M, Inoue A, Kobayashi K, Sugawara S, Oizumi S, Isobe H, et al. Gefitinib or chemotherapy for non-small-cell lung cancer with mutated EGFR. N Engl J Med (2010) 362(25):2380-8. doi:10.1056/NEJMoa0909530

34. Drummond MF, Sculpher MJ, Torrance GW, O’Brien BJ, Stoddart GL. Methods for the Economic Evaluation of Health Care Programmes. 3rd ed. New York: Oxford University Press (2005).

35. Mittmann N, Evans WK, Rocchi A, Longo CJ, Au HJ, Husereau D, et al. Guidelines for health technologies: specific guidance for oncology products in Canada. Value Health (2012) 15(3):580-5. doi:10.1016/j.jval.2011.12.006

36. Bradbury PA, Tu D, Seymour L, Isogai PK, Zhu L, Ng R, et al. Economic analysis: randomized placebo-controlled clinical trial of erlotinib in advanced non-small cell lung cancer. J Natl Cancer Inst (2010) 102(5):298-306. doi:10.1093/jnci/ djp518

37. Brown T, Boland A, Bagust A, Oyee J, Hockenhull J, Dundar Y, et al. Gefitinib for the first-line treatment of locally advanced or metastatic non-small cell lung cancer. Health Technol Assess (2010) 14(Suppl 2):71-9. doi:10.3310/ hta14Suppl2/10

38. de Lima Lopes G Jr, Segel JE, Tan DS, Do YK, Mok T, Finkelstein EA. Costeffectiveness of epidermal growth factor receptor mutation testing and first-line treatment with gefitinib for patients with advanced adenocarcinoma of the lung. Cancer (2012) 118(4):1032-9. doi:10.1002/cncr.26372
39. Handorf EA, McElligott S, Vachani A, Langer CJ, Bristol Demeter M, Armstrong $\mathrm{K}$, et al. Cost effectiveness of personalized therapy for first-line treatment of stage IV and recurrent incurable adenocarcinoma of the lung. J Oncol Pract (2012) 8(5):267-74. doi:10.1200/JOP.2011.000502

40. Brown T, Pilkington G, Bagust A, Boland A, Oyee J, Tudur-Smith C, et al. Clinical effectiveness and cost-effectiveness of first-line chemotherapy for adult patients with locally advanced or metastatic non-small cell lung cancer: a systematic review and economic evaluation. Health Technol Assess (2013) 17(31). doi: $10.3310 /$ hta 17310

41. Wang S, Peng L, Li J, Zeng X, Ouyang L, Tan C, et al. A trial-based cost-effectiveness analysis of erlotinib alone versus platinum-based doublet chemotherapy as first-line therapy for Eastern Asian nonsquamous non-smallcell lung cancer. PLoS One (2013) 8(3):e55917. doi:10.1371/journal.pone. 0055917

42. Zhou C, Wu YL, Chen G, Feng J, Liu XQ, Wang C, et al. Erlotinib versus chemotherapy as first-line treatment for patients with advanced EGFR mutation-positive non-small-cell lung cancer (OPTIMAL, CTONG-0802): a multicentre, open-label, randomised, phase 3 study. Lancet Oncol (2011) 12(8):735-42. doi:10.1016/S1470-2045(11)70184-X

43. Bajaj PS, Veenstra DL, Goertz HP, Carlson JJ. Targeted erlotinib for first-line treatment of advanced non-small cell lung cancer: a budget impact analysis. J Med Econ (2014) 12:1-9. doi:10.3111/13696998.2014.912987

44. Sequist LV, Yang JC, Yamamoto N, O’Byrne K, Hirsh V, Mok T, et al. Phase III study of afatinib or cisplatin plus pemetrexed in patients with metastatic lung adenocarcinoma with EGFR mutations. J Clin Oncol (2013) 31(27):3327-34 doi:10.1200/JCO.2012.44.2806

45. Wu YL, Zhou C, Hu CP, Feng J, Lu S, Huang Y, et al. Afatinib versus cisplatin plus gemcitabine for first-line treatment of Asian patients with advanced non-small-cell lung cancer harbouring EGFR mutations (LUX-Lung 6): an open-label, randomised phase 3 trial. Lancet Oncol (2014) 15(2):213-22. doi:10.1016/S1470-2045(13)70604-1

46. National Institute for Health and Care Excellence (NICE). Afatinib for Treating Epidermal Growth Factor Receptor Mutationpositive Locally Advanced or Metastatic Non-small-cell Lung Cancer. London: NICE (2014).

47. Goulart B, Ramsey S. A trial-based assessment of the cost-utility of bevacizumab and chemotherapy versus chemotherapy alone for advanced non-small cell lung cancer. Value Health (2011) 14(6):836-45. doi:10.1016/j.jval.2011.04.004

48. Fleeman N, Bagust A, McLeod C, Greenhalgh J, Boland A, Dundar Y, et al. Pemetrexed for the first-line treatment of locally advanced or metastatic non-small cell lung cancer. Health Technol Assess (2010) 14(Suppl 1):47-53. doi:10.3310/hta14Suppl1/07

49. Sequist LV, Heist RS, Shaw AT, Fidias P, Rosovsky R, Temel JS, et al. Implementing multiplexed genotyping of non-small-cell lung cancers into routine clinical practice. Ann Oncol (2011) 22(12):2616-24. doi:10.1093/annonc/mdr489

50. Buzdin AA, Zhavoronkov AA, Korzinkin MB, Venkova LS, Zenin AA, Smirnov PY, et al. Oncofinder, a new method for the analysis of intracellular signaling pathway activation using transcriptomic data. Front genet. (2014) 5:55. doi:10.3389/fgene.2014.00055

Conflict of Interest Statement: The authors declare that the research was conducted in the absence of any commercial or financial relationships that could be construed as a potential conflict of interest.

Received: 16 June 2014; accepted: 05 September 2014; published online: 22 September 2014.

Citation: Graham DM and Leighl NB (2014) Economic impact of tissue testing and treatments of metastatic NSCLC in the era of personalized medicine. Front. Oncol. 4:258. doi: $10.3389 /$ fonc.2014.00258

This article was submitted to Thoracic Oncology, a section of the journal Frontiers in Oncology.

Copyright (C) 2014 Graham and Leighl. This is an open-access article distributed under the terms of the Creative Commons Attribution License (CC BY). The use, distribution or reproduction in other forums is permitted, provided the original author (s) or licensor are credited and that the original publication in this journal is cited, in accordance with accepted academic practice. No use, distribution or reproduction is permitted which does not comply with these terms. 